\title{
NURSES' VOICE WHEN PERCEIVING THE PAIN OF CHILD BURN PATIENTS
}

\author{
Danelia Gómez-Torres ${ }^{1}$, Victoria Maldonado-González², Berenice Reyes-Robles ${ }^{3}$, Ana Laura Muciño-Carrera ${ }^{4}$
}

\footnotetext{
${ }^{1}$ P.H.D. R.N. Professor at faculty of nursing and obstetric. University of Mexico. Mexico. E-mail: gomezdanelia@usa.net

${ }^{2}$ MSC in anthropology. Professor at faculty of nursing and obstetric. University of Mexico. Mexico. E-mail: victmanmx@yahoo. com.mx

${ }^{3}$ RN. Faculty of nursing and obstetric University of Mexico. Mexico. E-mail: marusa_queen@hotmail.com

${ }^{4}$ RN. Faculty of nursing and obstetric University of Mexico. E-mail: anylaux_54@hotmail.com
}

\begin{abstract}
The objective of this study was to reveal nurses' perception in view of the nociceptive pain in child burn patients. This qualitative descriptive study was conducted at the Federal District Pediatric Hospital in Mexico City. Data were collected from semistructured interviews with ten nurses working in the burn unit; they were analyzed by content analysis, which yielded three categories. The theoretical framework was based on phenomenology. The results showed the nurses' experiences, their expression, and their selfdefense mechanisms, as revealed in the perception of their interventions. This highlighted the humanistic load regarding emotions, as the exposure to these feelings implies spending additional strength and energy, because the emotional work becomes more intense as their workloadincreases. Thus, the study concluded that subjects learn about their own experience through experience itself.
\end{abstract}

KEYWORDS: Nursing. Pain perception. Nociceptive pain. Burns. Humanism.

\section{VOZES DAS ENFERMEIRAS AO PERCEBEREM A DOR DO PACIENTE INFANTIL COM QUEIMADURAS}

RESUMO: O objetivo deste estudo foi revelar a percepção da enfermeira diante da dor nociceptiva do paciente infantil que sofreu queimaduras. Foi desenvolvido no hospital pediátrico do Distrito Federal, México. Trata-se de uma pesquisa qualitativa, do tipo descritivo. Para a coleta dos dados foi utilizada uma entrevista semiestruturada e aplicada a dez enfermeiras da área de queimados, sendo os dados analisados pelo método de análise de conteúdo, da qual emergiram três categorias. Utilizou-se como referencial teórico a Fenomenologia. Os resultados mostram as vivências das enfermeiras, a expressão, o mecanismos de conduta autodefensiva na percepção de suas intervenções, destacando-se a carga humanística em relação às emoções, pois a exposição a esses sentimentos implicará em um gasto extra de força e energia, sendo que o trabalho emocional se torna mais intenso a medida que essa demanda aumenta. Concluiu-se então que o sujeito aprende as vivências de si mesmo através da experiência.

PALAVRAS CHAVE: Enfermagem. Percepção da dor. Dor nociceptiva. Queimaduras. Humanismo.

\section{VOCES DE LAS ENFERMERAS AL PERCIBIR EL DOLOR DEL PACIENTE INFANTIL QUEMADO}

RESUMEN: El objetivo del estudio fue revelar la percepción de la enfermera frente al dolor nociceptivo del paciente infantil que sufre quemaduras. Desarrollado en un hospital pediátrico del Distrito Federal, México. Investigación cualitativa, de tipo descriptivo. Para la recolección se aplicó una guía de entrevista semiestructurada a diez enfermeras del área de quemados, siendo los datos analizados mediante análisis de contenido. Como resultados se obtuvieron tres categorías. Se utilizó como referencial teórico la fenomenología. Los resultados muestran las vivencias de las enfermeras, la expresión, del mecanismos de conducta auto-defensiva, en la percepción de sus intervenciones, se destaca la carga humanística que tienen las emociones, pues el hecho de manifestarlas implica un gasto extra de fuerza y energía, resultando que a mayor intensidad de la emoción a la que se enfrentan, más es el trabajo emocional que realizan. En conclusión el sujeto aprende las vivencias del yo por medio de la experiencia.

PALABRAS CLAVE: Enfermería. Percepción del dolor. Dolor nociceptivo. Quemaduras. Humanismo. 


\section{INTRODUCTION}

Pain is a manifestation considered to be an indicator or consequence of a dangerous pathogenic situation. It is a universal human experience, affecting all individuals of all races. At certain times in life, it is a common reason for requesting health services, and it is the first sign of multiple pathologies ${ }^{1}$.

Burns are some of the most frequent, serious and disabling injuries. Nurses' perception of pain shown by burn patients is an important theme for studies and for the treatment of pain as a symptom, as nurses and patients may have different cognitive frameworks to describe pain. Thus the importance of reporting the experiences nurses have had over the years as part of their professional life, disclosing notable differences in relation to patients' pain episodes and showing how nurses perceive this unpleasant symptom.

In this study, nurses show their defense mechanisms, behavioral components, emotions, self-perception of nursing interventions, and emotional aspects. The psychological and emotional characteristics of nurses were displayed while taking care of burn patients, showing them as highly humanistic people.

With this study, we seek to answer the basic questions: what is the nurses' experience in view of somatic nociceptive pain in burn patients? How do nurses perceive their actions when dealing with the pain of patients they are treating? The objective of this study was to answer these questions by showing the nurses' speech in view of somatic nociceptive pain in child burn patients, when dealing with the pain of such patients.

\section{METHODOLOGY}

This is a qualitative descriptive study, in which the social actors were nurses from the burn unit of a pediatric hospital in Mexico City. This institution is the reference hospital for child burn patients, offering care to children from newborns to 14-year-old adolescents. It has one intensive care unit and one intermediate care unit, representing total available beds.

The project was submitted to the Ethics Committee, and conforms to ethical practices as outlined in article 100 of the general law for health research in Mexico. After authorization of the protocol to obtain the required information, a guide for a semi-structured interview was developed. The next step was to conduct two pilot interviews to assess the reliability and understandability of the instrument. Subsequently, ten nurses answered the ten questions in their workplace. ${ }^{1}$ Then, to confirm the results, non-participant observation was conducted by researchers who witnessed the interventions of participating nurses on different shifts.

The inclusion criteria were as follows: nurses working in the burn unit for at least two years; substitute nurses were excluded. The nurses signed an informed consent form. The interviews were conducted from May to June 2012 on different shifts; they were recorded. After data collection, the resulting data were read and reread. The colorimetric technique was used to select transcendental contents, until the desired degree of saturation was achieved. This way, the contents obtained from the interviews and the field logs were combined; coding included constant comparison of phenomena and the formulation of basic questions for the study. In the transcription, codes were assigned, which yielded a list of categories that revealed the nurse identity and provided the required materials to conduct a speech analysis.

Next, the data was interpreted to answer the study questions, reporting the nurses' perception in view of somatic nociceptive pain in child burn patients. The data led to understanding of the human sensitivity of the nurses and revealed how their interventions affected their evaluation of their own feelings. Discussion of the results was based on Husserl's phenomenological theory, which shows how people act in relation to their past experiences. The phenomenological analysis allowed the decomposition of significations in elements, tracking of references to intentionally prior information, and finally achievement of absolute subjectivity as the source of the entire signification. This study is part of the research project titled "Hacer y decir de la enfermera ante el dolor nociceptivo somático del paciente infantil quemado", registered under 2993/2010SF at the Universidade Autônoma do Estado do México.

\section{RESULTS AND DISCUSSION}

\section{Defense mechanisms}

These are unconscious psychological mechanisms, through which one person reduces the consequences of a stressor to keep developing normally. ${ }^{2}$ In this sense, the interventions conducted by nurses in the burn unit lead to creation of de- 
fense mechanisms to maintain a level of mental health that generates functionality: I searched for courses of human development, thanatology, something that could help me deal with that, now I have another focus to prevent empathy at a degree that would make me involved with the patient (i 4). Defense mechanisms are incorrect ways to resolve psychological conflicts and may end up enabling mental and behavioral disorders and, in more extreme cases, the somatization of psychological conflicts and physical disorders that express such conflicts.

The most important defense mechanisms are: repression, identification, reaction formation and projection. [...] as if with time it's not that someone becomes inhuman, I believe we are not inhuman, we do things thinking: I know it hurts, but that's my job, the purpose of my job is to make you feel as good as possible when you leave [...] (i 11). This excerpt shows the level of affection with the human aspect of nurses, in agreement with Husserl's phenomenological theory, ${ }^{3}$ which states that, in transcendental acts, the individual learns the things of the world through external perception. With imminent acts, the individual learns about the experiences of " $\mathrm{I}$ " through representation, such as on reflection, as internal experiences need support that shows reality, and such experience is constructed in the individual through his/her own reflections.

It is necessary to go further and deeply analyze the real meaning of this symptom, not only in the theoretical perspective, but in the practical/experiential perspective of people who feel pain. ${ }^{4}$ In daily experience, nurses should acquire a defense mechanism in view of the pain of child burn patients, learning that pain cannot disturb their emotional state; however, they say the pain of others is perceived and they effectively learn by themselves how to develop protection for both the patient and their own well-being.

\section{Self-defensive behavior}

An attitude is a form of response to someone or something that is learned and relatively permanent. The term 'attitude' has been defined as an effective positive or negative reaction to one object or abstract or concrete proposition that has been denoted. Attitudes are learned and, consequently, they may be differentiated from biosocial reactions, such as hunger, thirst and sex, which are not learned. Attitudes tend to remain very stable over time, and they always aim at an object or idea in particular. A natural attitude is that of men of conscience, which helps guide them and ensure meaning to the dimension in which they live. Phenomenology describes it as a world of values and assets, a practical world. Attitude is the vehicle as disposition, which allows us to open the doors to other life-related situations. Transcending various community attitudes allows us to open ourselves to the world or expand our 'see-know' to distinct perspectives; for Husserl, ${ }^{3}$ it would be knowledge that would allow us to decode what is "there," "in view of," regarding a being released in the world that seeks to know it in its logical transcendence.

Attitudes are rarely an individual subject; in general, they come from population groups that we should consider with our highest degree of understanding. They are comprised of three elements: what a person thinks (cognitive component); what a person feels (affective component); and a person's tendency to show thoughts and emotions (behavioral component). Emotions are related to someone's attitudes as a reaction to certain situation, thing or person. We understand an attitude as a tendency, disposition or inclination to act in a certain way. However, in an attitude that precedes conduct, we can find several elements that include thoughts and emotions.

Behavioral conduct can become negative for several reasons, and this can be seen in some of the interviewees, who show their way to act when providing emotional support: [...] sometimes, you spend more time with the patient than the family or doctor or therapist, then, it's important, I believe that everything that happens is between the patient and us, it's very important that the patient feel more secure and less fearful, that's on you [...] (i 6). In routine work, nurses are exposed to unpleasant and disturbing situations; however, they have to change or deny their own feelings to make patients feel they are cared for and protected, regardless of what the nurses feel.

At this moment, a difference appears between experienced and displayed emotions. This implies additional strength and energy called "emotion work"; the more intense the emotion the nurse has to face, the more severe the emotion work that she performs, especially when projecting work experiences with personal experiences.

Nurses feel touched when dealing with the sensations of their patients because they feel empathy towards the patients. For this reason, in their continuous interactions in the stages of pain, nurses should offer psychological and emotional support in addition to the use of medication ${ }^{2}$. Nurses should absolutely handle their emotions 
effectively, as limited control could block attitudes and interventions that could favor their patients.

The emotional implications for health staff, especially in nursing, are not free of negative attitudes in view of pain, setting aside the connections among psychosocial, emotional and physical needs that occur in an integrated manner in human beings. That can be due to multiple factors, also related to nursing education, such as the concept of a "good nurse" used to involve the skill of hiding emotions and keeping them outside the workplace, where the expression of feelings is not allowed [...] I believe that such accumulated stress... and not letting it come out because a nurse has to be strong, a nurse should not cry, as we were taught at school, then you bring it with you, you end up bringing it home [...] (i 4); A daily action in nurses' routines in view of somatic nociceptive pain in child burn patients is their control. This type of intervention allows negative stimulation to nurses that take care of this type of patient. When contrasting perception and conduct, patients use their personal experience as the base, while nurses can relate their experience with pain in the group of patients they have treated for years. ${ }^{4}$ This background leads to high levels of anxiety, an important reason to seek to translate subjective data as objectively as possible; ${ }^{5}$ thus generating nurses' self-control.

\section{Emotion}

This is a mood state produced by impressions of senses, ideas or memories that are frequently translated into gestures, attitudes or other forms of expression. Emotions have an important role in our life, taking us from anger to excitement, from frustration to satisfaction; we feel our own emotions and emotions of other people every day. The key is to use emotions in a smart way, which is precisely what leads to emotional intelligence: Deliberately making our emotions work for our benefit, to help us control our conduct and our thoughts in order to obtain better results ${ }^{6 . .}$ Such emotions are reported by the interviewees: [...] I don't allow myself to suffer with the patient, if I notice the patient is suffering, I concentrate on my own activities and on reducing his pain, but I don't allow that to generate any sensation [...] (i 9). When nurses do not control their emotional state and this impulse is beyond control, denial of emotions can occur. Instability can also alter their physiological reactions, and such disturbances can become a disease for nurses, as seen in: [...] it makes you depressed, you feel impotent, because you can give them medication, but with time, they develop drug tolerance [...] if these are emotions that go beyond control and you feel their pain as human beings [...] (i 10); [...] It breaks your heart, even if you've been a nurse for a long time [...], if that generates emotions, sometimes sad emotions, in other moments of "shut up, I have a lot of things to do," then, although the patient is suffering and I feel bad because I'm healing him, I have to do it [...] (i 11).

Nurses show different emotional states in view of pain in child burn patients, mostly anguish, anxiety, impotence, and sadness, which are inevitable, although they have a long work trajectory; however, this does not prevent nurses, as human beings, from becoming sensitive to their patients' suffering. Likewise, impotence does not hinder their focus on work either.

In human beings, the experience of an emotion usually involves a number of cognitions, attitudes and beliefs about the world that we use to evaluate a concrete situation, which then influences the way the situation is perceived. For many years, emotions have been considered unimportant and more relevance has been given to the rational characteristics of human beings. But emotions, as they are affective states, indicate personal internal states, motivations, desires, needs and objectives. At only a few months old, we acquire basic emotions such as fear, boredom or happiness, which become more and more complex thanks to language. Every individual experiences an emotion in a unique manner, depending on his/her prior experiences, learning, character and concrete situation.?

The wide range of situations to which nurses are exposed during their interventions leads them to experience strong affective implications, forcing them to change or deny their emotions in order to display a proper image to patients, family members of patients and the institutions where they work. ${ }^{8}$ For these reasons, they have to keep their emotions under control and take care of their mental and physical health, involving real and potential psychological help, as evidenced by one of the interviewees: [...] we then told the chief of nursing that we needed psychological support, because in fact we couldn't unload these emotions we carry [...] I had to seek private support with a physician, I couldn't sleep because the fact that I couldn't keep my eyes open or get to sleep for a while made me see myself as a dead person, and that they were doing to my own body the debridement I had to practice on the patient [...] (i 4).

As nurses are the professionals who perform such practice, the impact in view of a child's pain 
produces deep effects on the person. And surely, behaviors have different expressions in changing circumstances. That is due to the way we emotionally react to such circumstances.

A distinction is made here between two ways to feel: based on sensory perception and based on subjective non-sensory experience, that is, not depending on physical sensations, like feeling sad. But, although we recognize the difference between these two ways to feel, we can't forget that people express their subjective experience through corporal references. This is explained in part by the fact that feelings and emotions are sensory marks. Thus, it is normal not to know how to describe a diffuse personal feeling, but somatize it with pain, a respiratory problem, or any other symptom located in another part of the body.

Although not all ways to feel are consequences of sensory stimulation, the subjective experience of feeling sad or happy is marked by a body sign, as if searching for a sensory reference to show a feeling or, in other words, emotion'. In this way, nurses try to obtain external psychological help due to the great impact the service to burn patients has on critical states of pain. They indicate that, in the beginning of their professional practice, they are not psychologically prepared to witness these facts that affect their daily life, as some of them mention somatizing the other person's pain: [...] I feel anguish, sometimes pain, yes, I feel anxiety, and I treat them [...] and sometimes I feel pain [...] (i 7).

Negative feelings, when taken into account in nursing practice, allow better actions for the promotion and maintenance of the health of health care providers, as, after such feelings are recognized, the behavior of health care providers will be better understood..$^{10}$ In this way it is possible to disregard any assumption or position that intends to give an absolute and true explanation. There is a world that anticipates scientific, ethical or esthetic activity, an originary and intuitive world called the world of life, ${ }^{3}$ in such way that a phenomenological description of emotion will express the essential structures of consciousness, as one emotion is precisely an expression of consciousness.

A starting point for understanding the actions of health professionals is to explain why the procedures are performed. When a patient, especially a child, understands the reason for the interventions and hears about why certain actions are performed, the child will feel more comfortable and develop internal values of behavior that will constitute the child's own consciousness of what is good and what is bad. This can be accomplished with brief, concrete explanations, suited to the child's age. Such actions can pull down barriers in nurse-patient interaction that occur in circumstances where the actions of health professionals are seen negatively: [...] this girl didn't cry, but she looked at me so fixedly that she made me cry, because I told her: don't look at me like that, don't look at me like that, you are making me feel bad! [...] the girl, with the way she looked at me, complained, scolded me, Why do you do that to me? Why do you hurt me like that?. That was one case that marked me. This girl was discharged from the hospital, her mother thanked me and the girl never gave me a smile. That hurts until today, because she left with this bad impression about me [...] (i 7).

This speech shows the nurse's affliction, but, once the fact, or what Husserl calls the experienced phenomenon, ${ }^{3}$ occurs, a rational explanation can be provided about how the nurse experiences her patient's pain. This nurse-patient interrelation shows the nurse's sensitivity when she feels guilty and hurt because the girl thinks the nurse is causing her damage. Even when it can be considering that the child's perception is wrong, the nurse should face this fact, highlighting that the person who is taken in by his/her emotions cannot be coherent, objective or logical. The phenomenological reflection releases individuals from losses and making decisions related to the domain of natural attitudes. In this sense, what should be done is to think of experiences acquired before all rationalization, imagination or conceptualization, to rebuild the new meaning or value of a nurse's practice.

\section{Emotional aspects of nurses}

In human beings, the experience of feeling emotions usually involves a number of cognitions, attitudes and beliefs about the world used to evaluate a concrete situation and, therefore, influence the way the situation is perceived ${ }^{11}$. Facial expressions also affect the person who is looking at us, changing his/her conduct. If we see someone crying, we get sad or serious and we may even cry with this person.

On the other hand, we can identify very well with the anger, happiness and sadness of people we observe. Everyone shows emotions depending on one's life history, related to learning, character and the concrete situation, as revealed by the interviewees: [...] as you are part of it, they are your children and you don't want them to suffer, you identify yourself with them as your family, you put yourself in their place, as if you projected such affection with the 
children, because you say: 'What if he were my son?' No, terrible, what would happen, right? When you have small children, you think about the affection with children [...] (i 3); [...] and I asked the child: "What did you feel?" I felt as if someone was pouring a bucket of cold water over me. I felt terrible! What I felt was that, I guess, I should be feeling like the mother of this child. This child should be cared for as if that was my child, this way you'll be able to understand, help the child and you'll perform better with that child, as if that was my own child [...] (i 7).

Emotional implications have an important role in the daily routine of nurses. Pain empathy can trigger different affective responses that encourage nurses to develop actions considering the affective state of nurses when they observe pain. The observer should be alert to the person in pain and his/her affective state will allow reassuring supporting conduct and other behaviors. ${ }^{12}$ Being aware of the beneficial affection that nurses provide to burn patients through their interventions is shown by interviewees when they describe their emotions regarding projections onto the children and family members, putting themselves in the place of the mother, or thinking that a similar situation could happen in their own family. For this reason, we disagree with study conducted by Achury, ${ }^{6}$ which says that in clinical practice, the approach to pain management by some health professionals has been limited to physiological and pharmacological control, putting aside the social and emotional components and their repercussions, as the interviewed nurses contradict this ideology.

\section{Self-perception in interventions}

Perception explains that everything we know and learn about our environment and ourselves has its origin in our senses, through the process of collection, analysis, interpretation and understanding of information we constantly receive. This mechanism is exactly what we call perception. ${ }^{13}$

The perception of the emotional impact from suffering burns is very high. The magnitude of the symptomatic condition depends on several factors related to burn severity; therefore, nurses face suffering and pain; and these conditions favor daily contact with human pain. However, nurses are vulnerable due to the interventions they perform. For this reason, they show their perception and feeling, as they are constantly in contact with so much suffering.
I feel anguish, despair, because for me, I can't describe what pain is like [...] then, when I see the child is suffering, I feel anguish, despair... (i 4); The baths were traumatizing, both for me and the patient [...] yes, it is dramatic, very strong (i 5); [...] but it also gives you the sensation of fulfillment, commitment, and, in the end, when the objectives are achieved, I believe you get great satisfaction [...]. This excerpt shows the human side of nurses, in view of such suffering, such aspects contribute to the generation of a high level of anxiety in providing the health care, a stimulation that favors both negative and positive emotions. This aspect is of great importance, because the expression of feelings can be positive or negative and these feelings should be taken into account in a relation to health care provision, once it allows acceptance and feeling what the other one is thinking, allowing full and effective integration of the beings involved. ${ }^{8}$ Likewise, Castro ${ }^{14}$ reports that emotions allow us to establish contacts with the world, relate quickly to unexpected facts, make decisions promptly and safely, and communicate verbally and non-verbally with other people, according to the concern of this human being that should offer humanized health care.

Nursing should have special and innovative elements to enable efficient and effective contributions to its interventions, with benefits to the population. It is necessary to develop new viewpoints that work together to help professionals act in new and varied scenarios, where commitment and social solidarity are reflected in every action. [...] sometimes I think: What am I going to do? Oh God, God, what should I do? What should I do? Sometimes I think, I don't know, if I had the power of just looking and removing, reducing the pain... Sometimes, at night, I think of what to do, what am I going to do with the child, what else I can do to help them, and then I'm thinking: Tomorrow I'll do this, and other things... sometimes I implement things... [...] (i 7).

Child care is a clear theme in the words of the interviewed nurses. When seeing the anguish, fear or suffering of these children, and within the limits imposed by their profession, they should offer emotional and affective support to the children, ${ }^{15}$ as well as creativity.

Today, nurses from all over the world periodically conduct innovative activities, motivated by the desire to improve results of the health care they provide to patients and the population in health systems. In these innovative initiatives, nurses seek to improve the quality of life for their patients and in the communities where they work. 
Just as the nursing action in this setting was revealed, it is desirable that such an exemplary attitude be extended to all health team members, keeping this more humane view, as it contributes to experiences in this type of health care, with the characteristic professionalism of nurses, by offering knowledge, skills and feelings in a positive manner to social order.

\section{CONCLUSIONS}

For nurses, caregiving involving painful processes creates unpleasant sensations, causing anguish, despair, and traumatic and dramatic situations, to the point of repressing tears. But, at the same time, it generates commitment, and a sense of fulfillment and satisfaction for having achieved the objectives of the intervention, thus showing their professionalism.

This study also concluded that the work of nurses demands a high level of psycho-emotional well-being, which helps prevent impacts on their mental health in significant events such as providing health care to child burn patients., to help prevent impacts on their mental health.; because, when reporting their experiences, they are dramatic for the multiple facts that they have experienced and overcome, which implies submitting their own feelings and changing their attitudes as persons. These are dramatic events that they have experienced and overcome, which implies that they submitted to their own feelings and changed their attitudes as persons.

In their workplace, nurses have interactions that demand their full attention, for which they should have support for competencies in all human areas. This is needed in order to help them control their own emotions and the emotions of others, when generating a state of painful crisis with their interventions, because, in difficult situations, they should bear the pain of patients, as the product of a human-to-human connection.

It should be noted that this study concluded that, compared to nurses with more experience, nurses with less professional experience interact with more authenticity with burn patients, showing more effective attitudes of sensitivity and empathy with children, helping ameliorate painful processes. This shows that length of service is a determinant to be considered by burn units in nurse turnover plans, seeking to foster human warmth in nursing interventions.

\section{REFERENCES}

1. Castañeda A. Accidentes pediátricos por quemaduras en el curso de la realización de vaporizaciones domesticas. [trabalho na internet]. México; 2009 [acceso 2013 Feb. 16] Disponible en: http:/ / www.monografias.com/trabajos66/ accidentes-pediatricos/accidentesdiatricos.shtml

2. Vargas RAM, Ortiz-Pérez LC. El dolor en el paciente quemado: intervenciones del psiquiatra de enlace. Cuadernos Psiquiat Enlace. 2008 Dic; (40):11-4.

3. Husserl E. Logical investigations. International Library of Psilosophy and scientific Method; NY (US): Ted Honderich; 1970.

4. Sloman R, Rosen G, Rom M, Shir Y. Nurses' assessment of pain in surgical patients. Journal Advanc Nursing [online]. 2005 [acceso 2013 Jun 19] 52(1):125-32. Disponible en: http:// onlinelibrary. wiley.com/doi/10.1111/j.1365-2648.2005.03573.x/ references

5. Curti BP, Tatsch NE, Castaldo RA. O manejo da dor em crianças com câncer construções para a enfermagem. Cogitare Enferm. 2011; 16(2):226-31.

6. Achury-Saldaña DM. Dolor: la verdadera realidad. Aquichan [online]. 2008 [acceso 2012 Mar 8]; 8(2). Disponible en: http:/ / redalyc.uaemex.mx/src/ inicio / ArtPdfRed.jsp?iCve=74180203

7. Guzman MD. Trabajar la inteligencia emocional es importante. Rev Digital Enfoq Educ. 2008; (22):12939. [acceso 2011 Mar 20]; Disponible en: www. enfoqueseducativos.es

8. Franco-Pérez R. El trabajo emocional. Implicaciones de enfermería. [pagina de internet] México: Portales Médicos; 2010 [acceso 2010 Dic 23]. Disponible en: http://www.portalesmedicos. com/publicaciones/articles/2618/1/El-trabajoemocional-Implicaciones-en-Enfermeria.html

9. Guedes SM, Álvaro JL. Naturaleza y cultura en el estudio de las emociones. Rev Española Soc [online]. 2010 [acceso 2011 Mar 20]; 10(13):31-47. Disponible en: http:/ / dialnet.unirioja.es/servlet/ articulo codigo $=3252882$ \&orden $=321343$ \&info $=$ link

10. Franck SL, Bruce E. Putting pain assessment into practice: why is it so painful. Pain Res Manag [online]. 2009 Jan-Feb [acceso 2013 Jun 22]; 14(1):1320. Disponible en: http:/ / www.ncbi.nlm.nih.gov/ pmc/articles/PMC2706559/

11. Schossler T, Crossetti MG. Cuidador domiciliar do idoso e o cuidado de si: uma análise através da teoria do cuidado humano de Jean Watson. Texto Contexto Enferm [online]. 2008 [acceso 2012 Mar 23]; 17(2):280-87. Disponible en: http://redalyc. uaemex.mx/redalyc/src/inicio/ArtPdfRed. jsp?iCve=71417209

12. García BPE. Las emociones. Centro Profesores Recursos Torrijos [online]. 2009 [acceso 2012 Ene 16]; Disponible en: http://www.cesdonbosco. 
com/lectura/WebTorrijos2/Programaciones/ emociones.pdf

13. Ojeda RM. Síndrome de Asperger en la universidad: percepción y construcción del conocimiento. España (ES). Club Universitario; 2008.

14. Castro GMC. Tanatología la inteligencia emocional y el proceso de duelo. México: Trillas; 2007.
15. Melo HC, AraújoSEG, Veríssimo AVR, Santos VEFA Alves ERP, Souza MHN. O ser-enfermeiro em face do cuidado à criança no pós-operatório imediato de cirurgia cardíaca. Anna Nery [online]. 2012 [acceso 2013 Jun 05]; 16(3):473-479. Disponible en: http:// www.redalyc.org/articulo.oa?id=127723305007 